\title{
EFEKTIVITAS METODE BAHTSUL MASA'IL DALAM MENINGKATKAN DAYA KRITIS DAN PARTISIPASI SISWA PADA PEMBELAJARAN FIKIH DI MADRASAH ALIYAH
}

\author{
EFFECTIVENESS OF BAHTSUL MASA'IL METHOD IN IMPROVING CRITICAL POWER \\ AND STUDENT PARTICIPATION IN FIKIH LEARNING IN MADRASAH ALIYAH \\ Cucu Hayati, Sukiman \\ Universitas Islam Negeri Sunan Kalijaga Yogyakarta \\ email: cucuhayati9390@yahoo.com, sukiman@uin-suka.ac.id
}

Naskah Diterima: 1 Januari 2020; Direvisi: 25 Maret 2020; Disetujui: 13 Agustus 2020

\begin{abstract}
This research aims to analyze the effectiveness of the bahtsul masa'il method in enhancing the critical power and participation of students in the jurisprudence study in Madrasah Aliyah. The research method used is a quasi-experimental research method with a non-equivalent control group design. The free variable $(X)$ in the study is a masa'il bahtsul method applied in the experimental class and associated variables $(Y)$ are critical power (Y1) and student participation (Y2). The sample of this study were 36 students of class XI Science as an experimental class and 32 students of Social Sciences class XI as a control class. Data collection techniques using interviews, questionnaires, and observations. Data analysis is done with a descriptive statistic test and an average difference test using the Independent sample test $t$ and $N$-gain. The results showed that there was a difference in the critical power and participation between experimental class students using the method of bahtsul masa'il with the control class who did not use the method bahtsul masa'il on Fiqh learning. Thus it can be concluded that the method of bahtsul masa'il effective to increase the critical power and participation of students in the study of fiqh in Madrasah Aliyah.
\end{abstract}

Keywords: Bahtsul masa'il; Critical power; Fiqh learning; Student participation

\begin{abstract}
Abstrak
Penelitian ini bertujuan untuk menganalisis efektivitas metode bahtsul masa'il dalam meningkatkan daya kritis dan partisipasi siswa pada pembelajaran Fikih di Madrasah Aliyah. Metode penelitian yang digunakan adalah metode penelitian quasi eksperimen dengan desain non-eqquivalent pretestposttest control group. Variabel bebas (X) dalam penelitian ini adalah metode bahtsul masa'il yang diterapkan di kelas eksperimen dan variabel terkait $(\mathrm{Y})$ adalah daya kritis $\left(\mathrm{Y}_{1}\right)$ dan partisipasi siswa $\left(\mathrm{Y}_{2}\right)$. Sampel penelitian ini adalah siswa kelas XI IPA yang berjumlah 36 anak sebagai kelas eksperimen dan siswa kelas XI IPS yang berjumlah 32 anak sebagai kelas kontrol. Teknik pengumpulan data menggunakan wawancara, angket, dan observasi. Analisis data dilakukan dengan uji statistik deskriptif dan uji beda rata-rata dengan menggunakan uji $\mathrm{t}$ (independent sample test) dan $N$-gain. Hasil penelitian menunjukan bahwa terdapat perbedaan daya kritis dan partisipasi antara siswa kelas eksperimen yang menggunakan metode bahtsul masa'il dengan kelas kontrol yang tidak menggunakan metode bahtsul masa'il pada pembelajaran Fikih. Dengan demikian dapat dinyatakan bahwa metode bahtsul masa'il cukup efektif untuk meningkatkan daya kritis dan partisipasi siswa dalam pembelajaran Fikih di Madrasah Aliyah.
\end{abstract}

Kata kunci: Bahtsul masa 'il; Daya kritis; Partisipasi siswa; Pembelajaran fikih 


\section{PENDAHULUAN}

Istilah Fikih bukan hal yang asing bagi umat Islam, terutama para siswa di madrasah. Fikih di madrasah dipelajari pada tingkat Madrasah Ibtidaiyah, Tsanawiyah hingga Aliyah (Menteri Agama, 2019). Mata pelajaran Fikih di Madrasah Aliyah adalah salah satu mata pelajaran Pendidikan Agama Islam yang merupakan peningkatan dari Fikih yang telah dipelajari oleh siswa di Madrasah Tsanawiyah dengan cara mempelajari, memperdalam serta memperkaya kajian Fikih baik yang menyangkut aspek ibadah maupun muamalah, yang dilandasi oleh prinsip-prinsip dan kaidahkaidah ushul fiqh (Soewarno, Alfan and Wahyudi, 2015). Tujuan pembelajarannya adalah agar siswa mampu mengetahui dan memahami prinsip-prinsip, kaidah-kaidah dan tata cara pelaksanaan hukum Islam sehingga siswa dapat menjawab pertanyaan-pertanyaan dan menyelesaikan problematika mereka, dengan berpedoman pada hukum-hukum syari'at. Tujuan selanjutnya adalah agar siswa dapat melaksanakan dan mengamalkan ketentuan hukum Islam dengan baik dan benar dalam kehidupan pribadi dan sosial (Menteri Agama, 2019).

Peningkatan pembelajaran Fikih Madrasah Aliyah dalam kurikulum 2013 yang diterbitkan oleh Direktorat Jenderal Pendidikan Agama Islam Kementerian Agama Indonesia adalah terlihat pada Kompetensi Inti (KI) pembelajaran, khususnya adalah Kompetensi Inti pada ranah kognitif (KI-3) dan Kompetensi Inti pada ranah keterampilan (KI-4). Di antara uraian kompetensi inti pengetahuan (KI-3) adalah memahami, menerapkan, menganalisis pengetahuan faktual, konseptual, prosedural berdasarkan rasa ingin tahunya tentang ilmu pengetahuan, teknologi, seni, budaya, dan humaniora dengan wawasan kemanusiaan, kebangsaan, kenegaraan, dan peradaban terkait penyebab fenomena dan kejadian, serta menerapkan pengetahuan prosedural pada bidang kajian yang spesifik sesuai dengan bakat dan minatnya untuk memecahkan masalah. Sedangkan kompetensi inti keterampilan (KI-4) adalah mengolah, menalar, dan menyajikan dalam ranah konkret dan ranah abstrak terkait dengan pengembangan dari yang dipelajarinya di madrasah secara mandiri, dan mampu menggunakan metode sesuai kaidah keilmuan (Soewarno, Alfan and Wahyudi, 2015).

Kompetensi yang diuraikan di atas, menunjukan bahwa pembelajaran Fikih di Madrasah Aliyah harus sudah menjangkau keterampilan berpikir tingkat tinggi (Higer Order Thinking Skills). Jika ditinjau berdasarkan ranah kognitif pada Taksonomi Bloom, kemampuan berpikir tingkat tinggi berada pada level analisis, evaluasi dan kreasi (W.Airasian et al., 2010), (Kuswana, 2014), dan (Sukiman, 2017). Untuk mengembangkan kemampuan berpikir kritis siswa, proses pembelajaran Fikih di Madrasah Aliyah seharusnya tidak lagi sebatas konsep yang hanya dihafal atau sebatas produk hukum yang bersifat mutlak. Tetapi lebih dari itu, pembelajaran Fikih haruslah menjadi sebuah proses untuk menghasilkan produk hukum. Fikih dalam arti proses, ialah memaksimalkan pembelajaran dengan pemikiran yang tinggi (Mukhsin, 2012). Karena pada dasarnya, Fikih merupakan hasil pemikiran manusia yang bersifat relatif dan lahir berdasarkan konteks situasi, waktu dan tempat. Seperti dikatakan dalam sebuah kaidah Fikih "beralihnya fatwa sesuai dengan peralihan zaman, tempat, adat dan kondisi". Keterampilan berpikir merupakan salah satu aspek penting dalam pembelajaran (Widana, 2017). Siswa yang dilatih untuk berpikir, menunjukkan dampak positif pada pengembangan pendidikan mereka, serta mempengaruhi kemampuan belajar siswa, kecepatan belajar dan efektivitas pembelajaran (Winarti, Sunarmo and Istiyono, 2015). Oleh karena itu, keterampilan berpikir perlu dikembangkan dalam proses pembelajaran.

Namun, secara umum pembelajaran Fikih di Madrasah Aliyah masih memproduksi pandangan- pandangan Fikih klasik serta tekstual, dan jarang sekali memproduksi pandangan-pandangan alternatif yang relevan dengan konteks kekinian. Sehingga karakteristik Fikih yang merupakan hukum Islam bagi semua umat (universal) dan selalu berada di posisi adil dan berimbang (moderat) mulai terlupakan. Apabila hal tersebut dibiarkan, suatu saat Fikih itu sendiri akan menjadi sebuah alat yang menimbulkan perpecahan dan legitimasi ekstrimitas kelompok tertentu untuk mendiskreditkan 
kelompok lainnya. Gejala-gejala pembelajaran Fikih seperti itu terjadi dalam pembelajaran Fikih di Madrasah Aliyah YPI Cikoneng Bandung. Berdasarkan hasil pengamatan awal, penulis memperoleh informasi dari Kepala Madrasah bahwa, pemahaman siswa terhadap materi Fikih cukup baik namun kemampuan mereka dalam menganalisis suatu persoalan dalam pembelajaran Fikih masih sangat kurang (Taufiq, 2019). Hal ini disebabkan karena proses pembelajaran Fikih masih menekankan pada aspek pengetahuan dan pemahaman materi. Guru selama ini lebih banyak memberikan latihan mengerjakan soal-soal pada buku paket, sehingga menyebabkan siswa kurang terlatih mengembangkan keterampilan berpikir dalam memecahkan masalah dan menerapkan konsep- konsep yang dipelajari di madrasah ke dalam kehidupannya sehari-hari (Taufiq, 2019). Dalam pembelajaran di kelaspun terlihat saat diberikan pertanyaan, hanya beberapa siswa saja yang menjawab pertanyaan. Kemudian, jawaban dari pertanyaan masih sebatas ingatan dan pemahaman saja, belum terdapat jawaban analisis terhadap pertanyaan guru. Partisipasi siswa dalam proses pembelajaran pun masih kurang. Hal ini terlihat dari sedikitnya siswa yang menunjukan keaktifan dalam proses pembelajaran.

Berangkat dari kondisi pembelajaran Fikih seperti itu, penulis tertarik untuk melakukan penelitian dengan mengujicobakan dan menganalisis efektivitas metode bahtsul masa'il dalam meningkatkan kemampuan daya kritis dan partisipasi siswa dalam pembelajaran Fikih di Madrasah Aliyah YPI Cikoneng Bandung. Solusi yang penulis tawarkan ini berangkat dari asumsi bahwa pada prinsipnya guru harus mampu menyajikan pembelajaran yang dapat menstimulus siswa untuk lebih aktif dalam menggunakan daya pikir kritis dan partisipasinya dalam proses pembelajaran. Berdasarkan asumsi kontruktivis, guru dapat membangun situasi-situasi sedemikian rupa sehingga siswa dapat terlibat aktif dalam proses pembelajaran melalui pengolahan materi-materi dan interaksi sosial (Suparno, 2001), (Budiningsih, 2005), dan (Schunk, 2012). Cara yang bisa dilakukan misalnya, dengan menyajikan beberapa problem faktual untuk dianalisis dan dikritisi oleh siswa sebagai proses pemecahan masalah melalui observasi dan pencarian informasi, kemudian siswa membuat kesimpulan dari hasil pemecahan masalah tersebut. Mengacu pada pemecahan masalah, model pembelajaran yang dapat diterapkan adalah model pembelajaran berbasis masalah (problem based learning/PBL) (Janawi, 2013). Menurut Sanjaya (2012), problem based learning betul-betul mengoptimalkan kemampuan siswa melalui proses kerja kelompok yang sistematis sehingga siswa dapat mengasah, menguji dan mengembangkan kemampuan berpikirnya. Dalam menyelesaikan persoalan Fikih, salah satu metode yang dapat digunakan adalah metode bahtsul masa'il. Bahtsul masa'il merupakan forum yang sangat dinamis, demokratis dan berwawasan luas. Dikatakan dinamis, sebab persoalan-persoalan (masa'il) yang dihadapkan selalu mengikuti perkembangan hukum di masyarakat. Demokratis, karena dalam forum tersebut tidak ada perbedaan antara kaum priyai, santri yang tua ataupun muda, kaum konservatif atau modernis dan lain sebagainya, pendapat siapapun yang paling kuat dan memiliki pijakan yang kokoh, maka pendapat itulah yang diterima. Dikatakan berwawasan luas, disebabkan dalam bahtsul masa'il tidak ada dominasi madzhab dan selalu sepakat dalam khilaf (Miri, 2005)

Berdasarkan latar belakang di atas, dikemukakan rumusan masalah dalam tulisan ini, yaitu: bagaimanakah penerapan metode bahtsul masa'il dalam meningkatkan daya kritis dan partisipasi siswa kelas XI pada pembelajaran Fikih di MA YPI Cikoneng Bandung? Bagaimanakah efektivitas metode bahtsul masa'il dalam meningkatkan daya kritis dan partisipasi siswa kelas XI pada pembelajaran Fikih di MA YPI Cikoneng Bandung? Sedangkan tujuan tulisan ini adalah: (1) untuk mendeskripsikan langkah penerapan metode bahtsul masa'il dalam meningkatkan daya kritis dan partisipasi siswa kelas XI pada pembelajaran Fikih di MA YPI Cikoneng Bandung, dan (2) untuk mengetahui efektifitas metode bahtsul masa'il dalam meningkatkan daya kritis dan partisipasi siswa kelas XI pada pembelajaran Fikih di MA YPI Cikoneng Bandung. 


\section{KAJIAN TEORI}

Ada beberapa konsep yang dijelaskan pada bagian ini, yaitu metode bahtsul masa'il, daya kritis, dan partisipasi siswa dalam pembelajaran.

\section{Bahtsul Masa'il}

Bahtsul masa'il sudah menjadi tradisi diskusi di banyak pesantren yang melibatkan kyai dan santri, di dalamnya membahas tentang permasalahan keagamaan dalam kehidupan sehari-hari, dan hukum-hukum Islam yang berkaitan dengan masalah-masalah Fikih ( masa'il fiqhiyah) yang terjadi dan dialami oleh masyarakat yang sering dikategorikan sebagai fikih kontekstual (Zahro, 2004). Menurut Rajafi (2015), fikih kontekstual adalah pemahaman yang berorientasi pada konteks pembaca teks dalil-dalil hukum. Bahtsul masa'il dapat dijadikan sebagai salah satu metode pembelajaran Fikih yang kontekstual. Melalui metode ini, pembelajaran Fikih dijadikan sebagai proses melatih pemikiran siswa dalam merespons persoalan-persoalan keagamaan yang dihadapi oleh siswa pada waktu, lokalitas ruang, dan lingkungan sosial masyarakat di sekitarnya. Dalam proses bahtsul masa'il terdapat beberapa aktivitas mental atau proses psikologis yang berhubungan dengan persepsi, pikiran, ingatan dan pengolahan informasi yang memungkinkan siswa untuk memperoleh pengetahuan, dan memecahkan masalah. Hal tersebut disebabkan karena guru menekankan pengalaman belajar siswa atau interaksi siswa dengan lingkungannya. Mengacu pada teori belajar konstruktivistik Piaget, bahwa rancangan belajar yang menggunakan metode bahtsul masa'il memberikan kesempatan pada siswa untuk mengemukakan gagasan dengan menggunakan bahasa mereka sendiri dan memberikan kesempatan kepada siswa untuk berpikir dan memikirkan tentang pengalamannya (Mulyasa, 2014). Proses pemerolehan dan pengolahan pengetahuan tersebut menjadikan setiap siswa lebih fleksibel dan bebas dalam memilih respons dan bertindak. Sementara itu, guru memosisikan diri sebagai pembimbing dan manusia sumber Sopiatin and Sahrani, 2011. Konsep-konsep yang jelas dalam metode bahtsul masa'il menjadikan siswa berpartisipasi secara mental dalam membangun struktur pengetahuannya sendiri dengan cara mengkritisi sebuah masalah yang disajikan oleh guru. Apabila guru dapat memaksimalkan pelaksanaan metode bahtsul masa'il dalam pembelajaran Fikih, maka tujuan pembelajaran Fikih dalam mengembangkan keterampilan berpikir tingkat tinggi dan mengolah pengetahuan secara mandiri dapat tercapai. Dalam pelaksanaan bahtsul masa'il, para siswa diminta untuk membuat konsep yang jelas dalam bentuk makalah kemudian dipresentasikan dalam forum bahtsul masa'il. Masing-masing siswa mengkritisi makalah yang dibuat dan didiskusikan bersama untuk mencari rumusan ketetapan hukum yang komprehensif (Arifi, 2010). Metode bahtsul masa'il ini menitikberatkan kepada kemampuan perseorangan di dalam menganalisis dan memecahkan masalah dengan argumen logika yang mengacu pada referensi tertentu (Arifi, 2010).

$\begin{array}{llr}\text { Bahtsul masa'il diterapkan sebagai } \\ \text { metode pembelajaran melalui } & \text { bingkai } \\ \text { penerapan suatu pendekatan atau model } & \text { moses } \\ \text { pembelajaran. } & \text { Berdasarkan } & \text { proses }\end{array}$
pelaksanaannya, metode bahtsul masa'il dapat diterapkan melalui pendekatan atau model pembelajaran problem based learning. Menurut Bern dan Erickson dalam Komalasari (2013), model pembelajaran problem based learning merupakan model pembelajaran yang melibatkan siswa dalam memecahkan masalah dengan mengintegrasikan berbagai konsep dan keterampilan dari berbagai disiplin ilmu. Harsono dalam Suprihatiningrum (2013) lebih lanjut menyatakan bahwa problem based learning adalah suatu model pembelajaran yang sejak awal menghadapkan siswa pada suatu masalah, kemudian diikuti oleh proses pencarian informasi yang bersifat student centered. Proses pembelajarannya melewati langkah-langkah dengan rumusan masalah, menganalisis, dan memecahkan masalah. Problem based learning bertujuan agar siswa mampu memperoleh dan membentuk pengetahuannya secara efisien, kontekstual, dan integratif. Menurut Rusman (2016), di antara beberapa karakteristik pembelajaran berbasis masalah adalah: (a) permasalahan menjadi start point dalam belajar; (b) permasalahan yang diangkat adalah permasalahan yang ada di dunia nyata yang tidak terstruktur; (c) permasalahan membutuhkan perspektif ganda; 
permasalahan menantang pengetahuan yang dimiliki oleh siswa, sikap, dan kompetensi; (e) pemanfaatan pengetahuan beragam dan evaluasi sumber informasi; dan (f) belajar adalah kolaboratif, komunikatif dan kooperatif
Pembelajaran berbasis masalah terdiri dari lima langkah utama yang dimulai dengan guru memperkenalkan siswa dengan suatu situasi masalah dan diakhiri dengan penyajian dan analisis hasil kerja siswa. Kelima langkah tersebut dijelaskan berikut ini (Suprihatiningrum, 2013):

Tabel 1. Langkah Pembelajaran Problem Based Learning

\begin{tabular}{|c|c|}
\hline Tahap & Tingkah Laku Guru \\
\hline Tahap-1 & enjelaskan tujuan pembelaja \\
\hline siswa pada masalah & $\begin{array}{l}\text { masalah, memotivasi siswa untuk terlibat dalam pemecahan } \\
\text { masalah yang dipilih. }\end{array}$ \\
\hline Tahap-2 & Guru membantu siswa untuk mendefinisikan dan \\
\hline $\begin{array}{l}\text { Mengorganisasi siswa untuk } \\
\text { belajar }\end{array}$ & $\begin{array}{l}\text { mengorganisasikan tugas belajar yang berhubungan dengan } \\
\text { masalah tersebut. }\end{array}$ \\
\hline Tahap-3 & siswa untuk mengumpulkan informasi yang \\
\hline Membimbing & oat memecahkan masalah. \\
\hline Inc & \\
\hline Tah & kan \\
\hline Men & perti laporan, \\
\hline$\Gamma \mathrm{a}$ & valuasi \\
\hline $\begin{array}{l}\text { Menganalisis dan men } \\
\text { proses pemecahan masal }\end{array}$ & likan mereka dan proses- proses yang mereka \\
\hline
\end{tabular}

\section{Daya kritis}

Kata "daya" dalam Kamus Besar Bahasa Indonesia memiliki arti kemampuan melakukan sesuatu atau kemampuan bertindak (Moeliono, 1990). Sementara, kata "kritis" diartikan sebagai sikap tidak lekas percaya, selalu berusaha menemukan kesalahan atau kekeliruan, tajam dalam penganalisaan (Bono, 2007). Kata kritis yang dimaksudkan mengarah kepada salah satu jenis kemampuan berpikir sebagaimana yang diungkapkan oleh Ashman Conway dalam Kuswana (2013), bahwa kemampuan berpikir melibatkan enam jenis, yaitu metakognisi, berpikir kritis, berpikir kreatif, proses kognitif (pemecahan masalah), berpikir inti (meringkas) dan memahami peran konten pengetahuan. Dewey dalam Suhardin (2018), menyatakan bahwa berpikir kritis adalah pertimbangan yang aktif, terus menerus dan teliti mengenai sebuah keyakinan atau bentuk pengetahuan yang diterima begitu saja dengan menyertakan alasan-alasan yang mendukung dan kesimpulan-kesimpulan yang rasional. Glaser dalam Fisher (2008), mendefinisikan berpikir kritis sebagai: (1) suatu sikap mau berpikir secara mendalam tentang masalah-masalah dan hal-hal yang berada dalam jangkauan pengalaman seseorang; (2) pengetahuan tentang metode-metode pemeriksaan dan penalaran yang logis; dan (3) semacam suatu keterampilan untuk menerapkan metode-metode tersebut. Berpikir kritis menuntut upaya keras untuk memeriksa setiap keyakinan atau pengetahuan asumtif berdasarkan bukti pendukungnya dan kesimpulan-kesimpulan lanjutan yang diakibatkannya.

Daniel Perkins dan Sarah Tishman dalam Santrock (2007), mengemukakan sejumlah indikator keterampilan berpikir kritis, yaitu: (a) berpikiran terbuka, yakni aktivitas otak yang terbuka terhadap berbagai ide, pandangan, argumen, data, teori dan kesimpulan. Lebih dari itu, berpikiran terbuka berarti membuka pikiran terhadap kemungkinan bahwa suatu ide, pandangan, data, teori dan kesimpulan bisa benar atau salah. Jika seseorang menerima dan mempercayai sesuatu tanpa mengujinya terlebih dahulu, maka ia disebut sebagai orang yang tidak kritis. Sebab, seseorang yang berpikir kritis seharusnya tidak berhenti memperimbangkan dan menguji pikiran- 
pikirannya terhadap berbagai bukti terkini yang relevan maupun argumen dan pandangan orang lain. (b) Rasa ingin tahu intelektual, yakni sikap dan tindakan yang selalu berupaya untuk mengetahui lebih mendalam dan meluas dari sesuatu yang dipelajarinya, dilihat dan didengarnya. Rasa ingin tahu merupakan hal yang penting bagi siswa karena munculnya rasa ingin tahu membuat siswa tidak diam menunggu arahan dari guru. (c) Perencanaan dan strategi, yakni dalam mencapai tujuan pembelajaran, guru dapat mengajak siswa untuk bekerja sama dalam memecahkan masalah secara terorganisir dengan cara bersama menyusun rencana, menentukan tujuan, mencari arah, menciptakan hasil dan mengevaluasi hasil kerja dibawah bimbingan guru. (d) Kehati-hatian intelektual, maksudnya adalah sikap hati-hati dalam menerima pengetahuan bisa disebut dengan skeptis. Secara umum, skeptisme adalah ketidakpercayaan atau keraguan seseorang tentang sesuatu yang belum tentu kebenarannya. Membangun sikap skeptis secara tidak langsung sudah mengajak kita untuk berpikir secara kritis untuk mengenali dan menggali kebenaran atas informasi-informasi.

\section{Partisipasi siswa}

Pengertian partisipasi menurut Moelyarto Tjokrowinoto dalam Suryobroto (2009) adalah penyertaan mental dan emosi seseorang di dalam situasi kelompok yang mendorong mereka untuk mengembangkan daya pikir dan perasaan mereka bagi tercapainya tujuantujuan, bersama tanggung jawab terhadap tujuan tersebut. Menurut Mulyasa (2005), konsep partisipasi adalah suatu gejala demokratis di mana orang diikutsertakan dalam perencanaan serta pelaksanaan dan juga ikut memikul tanggung jawab sesuai dengan tingkat kematangan dan tingkat kewajibannya. Partisipasi itu menjadi lebih baik dalam bidangbidang fisik maupun bidang mental serta penentuan kebijaksanaan. Knowles menyebutkan bahwa partisipasi dalam pembelajaran adalah adanya keterlibatan emosional dan mental peserta didik, adanya kesediaan peserta didik untuk memberikan kontribusi dalam pencapaian tujuan (Suryobroto, 2009). Dari beberapa pengertian partisipasi tersebut dapat ditarik kesimpulan bahwa partisipasi siswa dalam pembelajaran adalah keterlibatan siswa secara aktif baik mental, emosi serta fisik dalam kegiatan pembelajaran sehingga mendukung pencapaian tujuan pembelajaran secara efektif dan efisien. Partisipasi siswa dalam proses pembelajaran merupakan hal yang penting dalam rangka menciptakan proses pembelajaran yang aktif, kreatif, dan menyenangkan bagi siswa. Pembelajaran pada hakikatnya merupakan sebuah interaksi siswa dengan pendidik dan sumber belajar pada suatu lingkungan belajar sehingga terjadi perubahan perilaku pada diri siswa (Susanto, 2015). Dalam proses pembelajaran terjadi interaksi antar individu baik antara guru dengan siswa maupun antara siswa dengan siswa lainnya serta sumber belajar lainnya. Dalam proses interaksi tersebut terjadi proses dan peristiwa psikologis. Peristiwa dan proses psikologis ini sangat penting untuk dipahami dan dijadikan alasan oleh para guru dalam memperlakukan para siswanya secara tepat (Sopiatin and Sahrani, 2011). Menurut Sugiyono dan Hariyanto dalam Wiyani (2013), pengetahuan dalam pandangan konstruktivistik tidak dapat ditransfer begitu saja dari guru kepada siswa tetapi siswa sendiri harus berpartisipasi secara mental membangun struktur pengetahuannya. Oleh sebab itu, partisipasi siswa sangat penting agar mereka mengalami sendiri proses pembelajaran secara nyata dan realistik terhadap objek yang sedang dipelajari. Menurut Sardiman (2011), partisipasi siswa tidak hanya terlihat aktivitas fisiknya saja, tetapi juga ada keterlibatan psikis di dalamnya. Aspek aktivitas fisik dan aktivitas psikis antara lain: (a) Visual activities, antara lain aktivitas membaca dan memperhatikan; (b) oral activities seperti aktivitas menyatakan, bertanya, memberi saran, mengeluarkan pendapat, diskusi, interaksi dan sebagainya; (c) listening activities seperti mendengarkan uraian, percakapan atau diskusi; (d) writing activities seperti menulis, menyalin; (e) drawing activities seperti menggambar, membuat grafik, peta, dan sebagainya; (f) motor activities seperti melakukan percobaan, membuat model; (g) mental activities seperti menanggapi, memecahkan masalah, menganalisis, melihat hubungan, membuat kesimpulan; dan (h) emotional activities seperti 
menaruh minat, merasa bosan, gembira, tenang, dan sebagainya.

\section{METODOLOGI}

Pendekatan penelitian yang digunakan dalam penelitian ini adalah kuantitatif dengan jenis penelitian eksperimen. Penelitian eksperimen merupakan metode penelitian yang digunakan untuk mencari pengaruh perlakuan tertentu terhadap yang lain dalam kondisi yang terkendalikan (Moleong, 2005). Desain eksperimen yang dipilih quasi eksperimen dengan model non-eqquivalent pretets-posttest control group, di mana peneliti menerima kelompok atau kelas yang sudah ada sehingga tidak memungkinkan untuk menempatkan subjek secara random ke dalam kelompokkelompok (Sugiyono, 2014). Disain eksperimen yang digunakan dalam penelitian dapat digambarkan dalam skema berikut.

\begin{tabular}{|lll|}
$\mathrm{O} 1$ & $\mathrm{X}$ & $\mathrm{O} 2$ \\
$\mathrm{O} 3$ & & $\mathrm{O} 4$ \\
\hline
\end{tabular}

Variabel penelitian ini terdiri dari dua, yaitu variabel bebas $(\mathrm{X})$ dan variabel terikat (Y). Variabel bebas dalam penelitian ini adalah metode bahtsul masa'il yang diterapkan di kelas eksperimen pada pembelajaran Fikih, sedangkan variabel terikatnya ada dua, yaitu daya kritis siswa $\left(\mathrm{Y}_{1}\right)$ dan partisipasi siswa $\left(\mathrm{Y}_{2}\right)$.

Populasi sebagai wilayah generalisasi dalam penelitian ini adalah seluruh siswa kelas XI semester II MA YPI Cikoneng Bandung tahun pelajaran 2018-2019 yang secara keseluruhan terdiri dari dua kelas, yaitu kelas XI IPS dan kelas XI IPA. Teknik yang digunakan dalam menentukan sampel adalah sampel jenuh. Sampel jenuh adalah sampel yang diambil dari jumlah semua populasi dalam penelitian (Sukmadinata, 2010), hal ini terjadi karena populasi dalam penelitian sedikit. Selanjutnya, sampel penelitian dibagi menjadi dua kelompok, yaitu kelompok eksperimen dan kelompok kontrol. Penelitian ini memiliki dua kelompok yang berasal dari dua varians yang berbeda, yaitu kelas XI IPA yang berjumalh 36 anak dan kelas XI IPS yang berjumlah 32 anak. Karena sampel berasal dari varians yang berbeda, maka penulis menggunakan analisis statistik untuk melihat persamaan dua kelompok tersebut sehingga peneliti dapat memilih kelas eksperimen secara acak (Emzir, 2013).

Teknik pengumpulan data yang digunakan dalam penelitian ini adalah wawancara, angket, dan observasi. Wawancara digunakan untuk mengumpulkan data tentang pelaksanaan metode bahtsul masa'il dan partisipasi siswa dalam proses pembelajaran. Angket merupakan teknik pengumpulan data yang dilakukan dengan cara memberi seperangkat pertanyaan atau pernyataan tertulis kepada responden untuk dijawabnya (Sugiyono, 2014). Angket digunakan untuk memperoleh data tentang daya kritis dan partisipasi siswa. Angket yang digunakan adalah angket dengan skala $1-5$, di dalamnya disusun 20 pernyataan yang berhubungan dengan daya kritis dan partisipasi siswa. Observasi merupakan suatu teknik pengumpulan data dengan melakukan pengamatan terhadap obyek yang diteliti (Sukmadinata, 2010). Teknik observasi ini digunakan untuk mengamati pelaksanaan pembelajaran Fikih dengan metode bahtsul masa'il dan pembelajaran Fikih di kelas kontrol.

Analisis data penelitian dilakukan dengan menggunakan analisis statistik deskriptif dan uji beda dua rata-rata yang pengujiannya dengan menggunakan independent sample t-test. Pengambilan keputusan hasil uji $\mathrm{t}$ ( $t$-test) berdasarkan nilai signifikansi yaitu jika nilai probabilitas < 0,05 maka dinyatakan hipotesis alternatif $(\mathrm{Ha})$ diterima dan hipotesis nihil $(\mathrm{Ho})$ ditolak dan sebaliknya (Ghozali, 2008). Selanjutnya untuk mengetahui lebih lanjut tingkat efektifitas metode bahtsul masa'il ini dilakukan uji $N$-gain dari Hake (1999). Kriteria yang digunakan untuk menafsirkan hasil uji $\mathrm{N}$ gain adalah Efektif jika $N$-gain $>70,00 \%$, Cukup Efektif jika 30,00 $\geq N$-gain $\leq-70,00$, dan Kurang Efektif jika $N$-gain $<30,00$ (Hake, 1999; Sarasati, Harlanu and Sutarno, 2016; dan Situmorang, Muhibbuddin and Khairil, 2015).

\section{HASIL DAN PEMBAHASAN}

\section{Implementasi Metode Bahtsul Masa'il Pada Pembelajaran Fikih di MA}

Kegiatan pembelajaran yang baik senantiasa berawal dari rencana yang matang. Perencanaan yang matang akan menunjukan hasil yang optimal dalam pembelajaran. 
Kegiatan perencanaan merupakan tahapan persiapan untuk menerapkan metode bahtsul masa'il dalam meningkatkan daya kritis dan partisipasi siswa pada pembelajaran Fikih di MA YPI Cikoneng Bandung. Kegiatan perencanaan ini meliputi penyusunan silabus, rencana pelaksanaan pembelajaran (RPP), dan perencanaan penilaian pembelajaran. Silabus berisi uraian garis besar, ringkasan, ikhtisar, atau pokok-pokok isi materi pelajaran. Penyusunan silabus dilakukan oleh peneliti berdasarkan arahan dari pembimbing, guru Fikih di MA YPI Cikoneng dan merujuk pada Buku Guru Fikih Pendekatan Saintifik Kurikulum 2013 Kementerian Agama. Di dalam silabus tersebut, peneliti menjabarkan kompetensi inti, kompetensi dasar yang ingin dicapai, pokok-pokok serta uraian materi yang perlu dipelajari siswa, menentukan nilai yang akan dikembangkan, menyusun kegiatan pembelajaran, menentukan teknik penilaian dan menentukan model serta metode yang akan digunakan dalam rangka mencapai kompetensi inti dan kompetensi dasar. Setelah menyusun silabus, peneliti diberi kebebasan oleh guru Fikih di MA YPI Cikoneng Bandung untuk mengubah, memodifikasi dan menyesuaikan RPP materi pernikahan dalam Islam untuk tiga kali pertemuan pada pembelajaran Fikih kelas XI di MA YPI Cikoneng Bandung. Penyusunan RPP tersebut dilakukan pada awal penelitian dengan maksud agar RPP telah tersedia terlebih dahulu dalam setiap pelaksanaan pembelajaran dan sesuai dengan tahapan metode bahtsul masa'il yang akan diterapkan berdasarkan pendekatan problem based learning. RPP dikembangkan berdasarkan silabus yang telah disusun dalam bentuk rancangan proses pembelajaran untuk direalisasikan dalam pembelajaran dan disesuaikan dengan tujuan kurikulum 2013 yang tercantum dalam kompetensi inti dan untuk mengembangkan daya kritis dan partisipasi siswa. Penilaian dalam pembelajaran Fikih pada materi pernikahan dalam Islam di MA YPI Cikoneng Bandung disesuaikan dengan tema penelitian, yaitu menguji efektivitas bahtsul masa'il dalam meningkatkan daya kritis dan partisipasi siswa. Maka, instrumen penilaian yang dikembangkan disesuaikan dengan aspek yang dikembangkan yakni daya kritis dan partisipasi siswa.
Tahap selanjutnya adalah pelaksanaan pembelajaran Fikih dengan menggunakan metode bahtsul masa'il yang tahapannya meliputi kegiatan awal, kegiatan inti dan kegiatan akhir. Pada tahap kegiatan awal, mencakup tiga langkah, yaitu orientasi siswa pada masalah, mengorganisasi kegiatan belajar siswa, dan proses penyelidikan/pencarian informasi. Pada langkah pertama, guru mengajukan beberapa tema masalah yang berhubungan dengan kehidupan lingkungan siswa. Masalah tersebut dijadikan sebagai bahan pembelajaran untuk menstimulus daya kritis dan partisipasi siswa. Tema permasalahan yang dibahas dalam bahtsul masa'il pada pembelajaran Fikih kelas XI di MAYPI Cikoneng Bandung adalah: (1) Tema masalah pada materi rukun nikah, syarat nikah dan mahram nikah meliputi hukum menikahi pasangan yang melakukan operasi ganti kelamin dan menikahi saudara sesusuan; dan (2) Tema masalah pada materi macam-macam pernikahan terlarang yang meliputi hukum menikahi wanita yang dihamili orang lain dan nikah muhalil. Setelah guru menyajikan tema masalah, berlanjut pada langkah kedua pembelajaran yaitu mengorganisasi siswa untuk belajar. Pada tahap ini, guru memberikan penjelasan tentang langkah-langkah pemecahan masalah, kemudian membagi siswa menjadi empat kelompok. Setelah itu, siswa berkumpul bersama kelompoknya masing-masing mendiskusikan perencanaan dan sistem pemecahan masalah yang akan digunakan sebelum mencari informasi dan melakukan analisis di lapangan. Tetapi, pada tahap ini masih ada beberapa siswa yang tidak berpartisipasi memberikan ide- ide atau gagasan perencanaan pemecahan masalah. Hal tersebut dikarenakan jumlah siswa dalam setiap kelompok yang membatasi kesempatan beberapa siswa untuk berpartisipasi. Pada langkah ketiga, siswa mengumpulkan informasi di lapangan sesuai dengan masalah yang akan dipecahkan. Secara berkelompok, mereka mengidentifikasi masalah dan menyusun pemecahan masalah berdasarkan referensi yang mereka pilih, ada yang merujuk pada buku Fikih kurikulum 2013, buku-buku keagamaan yang bersangkutan, kitab-kitab Fikih terjemah, internet, dan lainnya. Hasil pemecahan masalah 
mereka susun dalam sebuah makalah yang akan dipresentasikan dalam forum bahtsul masa'il.

Tahap kegiatan inti yakni tahap pelaksanaan bahtsul masa'il meliputi beberapa kegiatan, yaitu: (1) Pembukaan atau muqaddimah oleh guru sebagai ketua sidang bahtsul masa'il; (2) Deskripsi masalah yang dilaksanakan oleh siswa yang menyajikan makalah. Setiap siswa masing-masaing kelompok mendapat tugas yang berbeda-beda. Beberapa tugas yang dibagikan kepada individu dari tiap kelompok adalah menjelaskan gambaran masalah, mambahas hukum dari berbagai pandangan ulama/ahli agama, membahas hukum berdasarkan undang-undang, menjawab pertanyaan dan memberikan pandangan serta argumen-argumen yang diperdebatkan; (3) Pengajuan pertanyaan dari kelompok lain terhadap kelompok yang sedang menyajikan makalah; (4) Penyampaian jawaban yang dilaksanakan oleh siswa yang menyajikan makalah; dan (5) Perdebatan argumen (i'tirodl). Pada tahap ini, peneliti menilai bahwa guru kurang memainkan perannya sebagai moderator yang memandu sesi debat siswa, sehingga perdebatan kurang terarah.

Tahap kegiatan akhir adalah evaluasi yang dilakukan oleh guru sebagai ketua sidang bahtsul masa'il. Pada tahap ini, guru berperan sebagai mushahhih yang bertugas untuk mengevaluasi hasil diskusi siswa berupa pencerahan referensi, memberikan tabbayun tentang perbedaan pendapat yang terjadi dalam bahtsul masa'il dan memberikan pengesahan jawaban.

\section{Evaluasi Penerapan Metode Bahtsul Masa'il pada Pembelajaran Fikih di MA}

Setiap metode memiliki kelebihan dan kekurangan. Kelebihan bahtsul masa'il adalah merangsang daya berpikir siswa dan memberikan kesempatan kepada siswa untuk dapat berperan aktif dalam proses pembelajaran. Selain itu, ada beberapa kelebihan yang peneliti temukan dari hasil pengamatan di lapangan, di antaranya adalah: (a) Menjadikan materi pembelajaran menjadi lebih relevan dengan kehidupan, (b) Melatih siswa untuk menghadapi masalah dan memecahkan masalah secara sistematis, (c) Membuka kesempatan bagi siswa untuk mengemukakan gagasan dengan menggunakan bahasa mereka sendiri, (d) Memberikan kesempatan kepada siswa untuk berpikir dan memikirkan tentang pengalamannya, (d) Menjadikan siswa berpartisipasi secara mental dalam membangun struktur pengetahuannya sendiri dengan cara mengkritisi sebuah masalah yang disajikan oleh guru, (e) Melatih siswa dalam menyikapi problematika umat, (f) Melatih siswa untuk mencari dasar atau dalil dalam menjawab problematika kontemporer.

Beberapa kekurangan penerapan metode bahtsul masa'il dalam pembelajaran Fikih di MA YPI Cikoneng Bandung adalah: (a) Memerlukan keterampilan guru dalam menentukan suatu masalah yang tingkat kesulitannya sesuai dengan tingkat berpikir siswa, (b) Kurangnya pengetahuan guru dan keahlian guru tentang langkah penerapan bahtsul masa'il, (c) Guru kurang memotivasi siswa agar berani untuk memberi tanggapan dan menyampaikan pendapatnya, (d) Proses belajar dengan menggunakan metode bahtsul masa'il memerlukan waku yang cukup banyak. Waktu yang terbatas menyebabkan pembahasan materi yang kurang maksimal, (e) Masalah yang disajikan dalam bahtsul masa'il merupakan masalah yang membutuhkan kemampuan berpikir cukup tinggi, sehingga umumnya yang dapat mengikuti pembelajaran dengan baik adalah siswa yang tergolong berkemampuan tinggi dalam berpikir.

Setiap kekurangan yang peneliti temukan disebabkan karena bahtsul masa'il belum terbiasa diterapkan sebagai metode pembelajaran di kelas. Mengubah kebiasaan siswa dari mendengarkan dan menerima informasi dari guru, menjadi belajar dengan banyak berpikir memecahkan permasalahan sendiri atau kelompok yang kadang-kadang memerlukan berbagai sumber belajar, merupakan kesulitan tersendiri bagi siswa maupun guru.

\section{Kondisi Awal Daya Kritis dan Partisipasi Siswa pada Pembelajaran Fikih}

Penelitian ini berupaya untuk menganalisis pengaruh penerapan metode bahtsul masa'il terhadap kemampuan daya kritis dan partisipasi siswa dalam proses pembelajaran Fikih di MA. Untuk melakukan 
analisis dilakukan dengan membandingkan hasil pembelajaran kelompok eksperimen dan kelompok control. Pada tahap awal dilakukan pre test untuk melihat kondisi awal kemampuan

Tabel 2. Nilai Pre Test Daya Kritis dan Partisipasi Siswa

\begin{tabular}{clcccc}
\hline Variabel & \multicolumn{1}{c}{ Kelas } & N & Rata-Rata & Simpangan Baku & Varians \\
\hline Daya Kritis Siswa & Eksperimen & 36 & 60,86 & 4,758 & 22,637 \\
& Kontrol & 32 & 59,00 & 6,122 & 37,484 \\
Partisipasi Siswa & Eksperimen & 36 & 62,69 & 4,921 & 24,215 \\
& Kontrol & 32 & 62,34 & 5,439 & 29,588 \\
\hline
\end{tabular}

Pada tabel. 2 di atas diketahui rata-rata nilai kemampuan daya kritis antara kelompok eksperimen dan kelompok kontrol, yakni untuk kelompok eksperimen diperoleh rata-rata nilai sebesar 60,86 dan kelompok kontrol sebesar 59,00. Dengan demikian dapat dipahami bahwa kemampuan awal daya kritis kedua kelompok relatif sama. Pada tabel. 2 juga diketahui ratarata nilai tingkat partisipasi siswa antara kelompok eksperimen dan kelompok kontrol, yakni untuk kelompok eksperimen diperoleh rata-rata nilai sebesar 62,69 dan kelompok kontrol sebesar 62,34. Dengan demikian dapat dipahami bahwa kondisi awal tingkat partisipasi siswa pada kedua kelompok relatif sama juga. Berdasarkan data ini dapat disimpulkan bahwa

Tabel 3. Hasil Uji Independent Sample Test Data Pre-Test Daya Kritis dan Partisipasi Siswa

\begin{tabular}{|c|c|c|c|c|c|}
\hline \multirow[b]{2}{*}{ Variabel } & & $\begin{array}{c}\text { Levene's Test for } \\
\text { Equality of Variances }\end{array}$ & \multicolumn{3}{|c|}{ t-test for Equality of Means } \\
\hline & & Sig. & $\mathrm{T}$ & Df & Sig. (2-tailed) \\
\hline \multirow[t]{2}{*}{ Daya Kritis Siswa } & Equal variances assumed & 0,036 & 1,408 & 66 & 0,164 \\
\hline & $\begin{array}{l}\text { Equal variances not } \\
\text { assumed }\end{array}$ & & 1,387 & 58,328 & 0,171 \\
\hline \multirow[t]{2}{*}{ Partisipasi Siswa } & Equal variances assumed & 0,676 & 0,279 & 66 & 0,781 \\
\hline & $\begin{array}{l}\text { Equal variances not } \\
\text { assumed }\end{array}$ & & 0,277 & 62,987 & 0,782 \\
\hline
\end{tabular}

Pada tabel. 3 di atas diketahui nilai Sig. Levene's Test of Variances kemampuan awal daya kritis siswa sebesar 0,036 dan partisipasi siswa sebesar 0,676. Karena nilai signifikansi kedua kemampuan tersebut lebih kecil dari 0,05 , maka dapat diartikan bahwa varians data antara kelompok eksprimen dan kelompok kontrol tidak homogen, sehingga untuk penafsiran hasil analisis uji t dengan mengacu pada nilai yang terdapat dalam tabel equal variances not assumed. Dari tabel. 4 di atas kedua kelompok siswa sebelum ada perlakuan memiliki kemampuan daya kritis dan tingkat partisipasi yang berimbang/relatif sama. Jika dilihat dari simpangan baku dan varians nilai hasil pre test tersebut, nilai kelompok kontrol lebih besar dari pada kelas eksperimen. Hal ini menunjukan bahwa, daya kritis dan partisipasi siswa kelas kontrol lebih bervariasi jika dibandingkan dengan daya kritis siswa kelas eksperimen. Selanjutnya untuk memastikan hasil analisis deskriptif ini, dilanjutkan dengan uji beda rata-rata dengan menggunakan uji $\mathrm{t}(t$ test) antara nilai pre test kelompok eksperimen dan kelompok kontrol. Hasil analisis dapat dilihat pada tabel 3 di bawah ini.

Levene's Test for

pada bagian equal variances not assumed diketahui nilai signifikansi (sig.2-tailed) uji-t daya kritis siswa kelas eksperimen dan kelas kontrol adalah 0,171 lebih besar dari 0,05 yang berarti tidak ada perbedaan rata-rata nilai kemampuan awal daya kritis siswa di kedua kelompok. Demikian juga nilai signifikansi (sig.2-tailed) uji-t partisipasi siswa pada kelas eksperimen dan kelas kontrol sebesar 0,782 lebih besar dari 0,05 yang berarti tidak ada perbedaan rata-rata nilai partisipasi siswa pada 
kedua kelompok. Dengan demikian dapat disimpulkan bahwa baik berdasarkan analisis deskriptif maupun uji $\mathrm{t}$ ( $t$ test), kondisi awal kemampuan daya kritis dan partisipasi siswa pada kelompok eksperimen dan kelompok kontrol relatif sama. Kondisi awal kemampuan daya kritis dan tingkat partisipasi kedua kelompok tersebut sangat cocok untuk pelaksanaan eksperimen sesuai dengan desain eksperimen yang digunakan yakni The NonEqquivalent Pretest-Posttest Control Group Design. Menurut Emzir (2013), penelitian eksperimen dengan desian tersebut akan lebih baik jika kondisi awal kedua kelompok sama atau relatif sama. Sugiyono (2014) juga menyatakan hal yang sama bahwa hasil pre test yang baik bila nilai kelompok eksperimen tidak berbeda secara signifikan dengan nilai kelompok kontrol.

\section{Metode Bahtsul Masa'il dan Peningkatan Daya Kritis dan Partisipasi Siswa pada Pembelajaran Fikih}

Pembahasan pada bagian ini untuk menjelaskan efektivitas penerapan metode bahtsul masa'il dalam meningkatkan daya kritis dan partisipasi siswa dalam pembelajaran Fikih di MA YPI Cikoneng Bandung. Hipotesis yang diajukan pada awal penelitian berbunyi "Penerapan metode bahtsul masa'il efektif dalam meningkaptkan daya kritis dan partisipasi siswa dalam pembelajaran Fikih di MA YPI Cikoneng Bandung". Untuk menguji efektif tidaknya metode bahtsul masa'il tersebut dilakukan dengan melihat ada tidaknya perbedaan daya kritis dan partisipasi antara siswa kelas eksperimen yang menggunakan metode bahtsul masa'il dengan kelas kontrol yang tidak menggunakan metode bahtsul masa'il dalam pembelajaran Fikih di MA YPI Cikoneng Bandung. Jika daya kritis dan partisipasi siswa kelas eksperimen lebih tinggi dari pada siswa kelas kontrol, maka kesimpulannya penerapan metode bahtsul masa'il efektif dalam meningkatkan daya kritis dan partisipasi siswa dalam pembelajaran Fikih di MA YPI Cikoneng Bandung dan sebaliknya.

Analisis dilakukan terhadap data hasil post test setelah ada perlakuan terhadap kelompok eksperimen. Analisis dilakukan secara deskriptif dan uji beda rata-rata dengan menggunakan uji t (t-test). Analisis pertama dilakukan secara deskriptif. Hasil analisis deskriptif data hasil post-test kemampuan daya kritis dan partisipasi kelas eksperimen dan kelas kontrol dapat dilihat pada tabel 4 di bawah ini.

Tabel 4. Analisis Deskriptif Hasil Post-Test tentang Daya Kritis dan Partisipasi Siswa

\begin{tabular}{cllccc}
\hline Variabel & \multicolumn{1}{c}{ Kelas } & N & Rata-Rata & Simpangan Baku & Varians \\
\hline Daya Kritis Siswa & Eksperimen & 36 & 79,67 & 7,728 & 59,714 \\
& Kontrol & 32 & 58,09 & 6,606 & 43,636 \\
Partisipasi Siswa & Eksperimen & 36 & 86,67 & 6,432 & 41,371 \\
& Kontrol & 32 & 64,22 & 4,743 & 22,499 \\
\hline
\end{tabular}

Dari tabel 4 di atas dapat dilihat bahwa rata-rata nilai (mean) post test daya kritis siswa kelas eksperimen lebih besar dibandingkan dengan kelas kontrol, yaitu 79,67 untuk ratarata nilai kelas eksperimen dan 58,09 untuk kelas kontrol. Jika dilihat dari simpangan bakunya kelas eksperimen lebih besar dibandingkan dengan kelas kontrol, yaitu 7,728 untuk kelas eksperimen dan 6,606 untuk kelas kontrol. Berdasarkan rata-rata nilai dan simpangan bakunya (varians) menunjukan bahwa setelah proses pembelajaran Fikih, daya kritis siswa kelas eksperimen lebih tinggi dan bervariasi jika dibandingkan dengan daya kritis siswa kelas kontrol. Demikian juga dengan ratarata nilai (mean) post test partisipasi siswa kelas eksperimen lebih besar dibandingkan dengan kelas kontrol, yaitu 86,67 untuk kelas eksperimen dan 64,22 untuk kelas kontrol. Jika dilihat dari simpangan bakunya kelas eksperimen juga lebih besar dibandingkan dengan kelas kontrol, yaitu 6,432 untuk kelas eksperimen dan 4,743 untuk kelas kontrol. Dengan data ini menunjukan bahwa setelah proses pembelajaran, tingkat partisipasi siswa kelas eksperimen lebih tinggi dan bervariasi jika dibandingkan dengan partisipasi siswa kelas kontrol. Dengan demikian berdasarkan analisis deskriptif hasil post test ini dapat disimpulkan bahwa penerapan metode bahtsul masa'il dalam pembelajaran Fikih di Madrasah Aliyah efektif 
dalam meningkatkan daya kritis dan partisipasi siswa dalam pembelajaran.

Analisis lebih lanjut untuk menguji signifikasi hasil analisis deskriptif ini dilakukan dengan uji beda rata-rata dengan menggunakan uji $\mathrm{t}$ (t-test) antara nilai post test kelompok eksperimen dan kelompok kontrol. Sebelum dilakukan uji $\mathrm{t}$ terlebih dahulu dilakukan uji normalitas sebagai persyaratan untuk uji t. Hasil uji normalitas data post test daya kritis kelas eksperimen adalah 0,177 dan kelas kontrol
0,200. Sedangkan data post test partisipasi siswa kelas eksperimen dan kelas kontrol adalah 0,200 . Karena seluruh nilai signifikansi baik untuk daya kritis maupun partisipasi siswa pada kedua kelas lebih dari 0,05, maka dapat dinyatakan bahwa data-data tersebut semuanya berdistribusi normal dan memenuhi syarat untuk analisis uji beda rata-rata dengan uji $\mathrm{t}(t$ test). Adapun hasil analisis uji beda rata-rata dengan uji $\mathrm{t}$ ( $t$-test) antara nilai post test kelompok eksprimen dan kelompok kontrol dapat dilihat pada tabel 5 di bawah ini.

Tabel 5. Hasil Uji Independent Sample Test Data Post-Test Daya Kritis dan Partisipasi Siswa

\begin{tabular}{clcccc}
\hline & \multicolumn{3}{c}{$\begin{array}{c}\text { Levene's Test for } \\
\text { Equality of Variances }\end{array}$} & \multicolumn{2}{c}{ t-test for Equality of Means } \\
\hline Dariabel & \multicolumn{1}{c}{ Sig. } & T & Df & Sig. (2-tailed) \\
\hline Pritis Siswa & $\begin{array}{l}\text { Equal variances } \\
\text { assumed }\end{array}$ & 0,282 & 12,294 & 66 & 0,000 \\
Partisipasi Siswa & $\begin{array}{l}\text { Equal variances } \\
\text { not assumed } \\
\text { Equal variances } \\
\text { assumed } \\
\text { Equal variances } \\
\text { not assumed }\end{array}$ & 0,055 & 12,409 & 65,909 & 0,000 \\
\hline
\end{tabular}

Berdasarkan hasil analisis uji perbedaan dua rata-rata yang disajikan pada tabel 5 di atas, terlihat pada kolom Levene's Test for Equality of Variances, nilai signifikansi daya kritis sebesar 0,282 dan partisipasi sebesar 0,055. Nilai signifikansi kedua variabel lebih besar dari 0,05. Hal tersebut menunjukkan bahwa kedua varians adalah sama, maka penggunaan varians untuk membandingkan rata-rata populasi (t-test for Equality of Means) dalam pengujian t-test harus dengan dasar equal variances assumed. Pada equal variance assumed nilai t daya kritis sebesar 12,294 dan partisipasi sebesar 16,205 dengan taraf signifikansi keduanya adalah 0,000. Hasil tersebut menunjukan bahwa $p<0,05$, berarti terdapat perbedaan yang signifikan antara daya kritis dan partisipasi siswa kelas eksperimen yang menggunakan metode bahtsul masa'il dengan siswa kelas kontrol yang tidak menggunakan metode bahtsul masa'il. Berdasarkan hasil analisis $N$-gain diperoleh rata-rata skor $N$-gain aspek daya kritis untuk kelas eksperimen sebesar 49,47 atau $49,47 \%$ berada dalam kategori cukup efektif, sementara untuk kelas kontrol sebesar 2,55 atau 2,55\% berada dalam kategori tidak efektif. Hasil analisis $N$-gain untuk aspek partisipasi siswa pada kelas eksperimen diperoleh rata-rata skor $N$-gain sebesar 65,7 atau $65,7 \%$ berada dalam kategori cukup efektif, sedangkan untuk kelas kontrol sebesar 4,27 atau 4,27\% berada dalam kategori tidak efektif. Jadi, berdasarkan hasil analisis $\mathrm{N}$-gain terdapat perbedaan peningkatan baik untuk aspek daya kritis maupun partisipasi siswa antara kelas eksperimen dengan kelas kontrol. Peningkatan daya kritis dan partisipasi siswa kelas eksperimen lebih tinggi dari pada kelas kontrol. Dengan demikian dapat disimpulkan bahwa penerapan metode bahtsul masa'il cukup efektif dalam meningkatkan daya kritis dan partisipasi siswa pada pembelajaran Fikih di MA YPI Cikoneng Bandung.

Berdasarkan hasil analisis di atas terbukti bahwa daya kritis dan partisipasi siswa kelas eksperimen dengan kelas kontrol berbeda. Daya kritis dan partisipasi siswa kelas eksperimen lebih baik dari pada kelas kontrol. Hal tersebut terjadi karena di kelas eksperimen menggunakan metode bahtsul masa'il. Sebelum 
diterapkan bahtsul masa'il, siswa kurang terlatih mengembangkan keterampilan berpikir dalam memecahkan masalah dan menerapkan konsep-konsep yang dipelajari di madrasah ke dalam kehidupannya sehari-hari. Hal tersebut dapat teratasi dengan diterapkannya metode bahtsul masa'il, karena berdasarkan hasil penelitian ini terbukti bahwa metode bahtsul masa'il efektif dalam meningkatkan daya kritis dan partisipasi siswa. Keefektifannya adalah bahtsul masa'il terbukti sebagai proses pendidikan kritis, yaitu siswa belajar dari realita atau pengalaman, dialogis dan tidak menggurui. Dikatakan belajar dari realita, karena masalah yang disajikan adalah masalah-masalah keagamaan yang sering ditemukan dalam kehidupan sehari-hari siswa. Dikatakan dialogis, karena dalam bahtsul masa'il terdapat proses dan pristiwa psikologis berupa interaksi, baik interaksi antara guru dengan siswa, siswa dengan siswa lainnya dan siswa dengan lingkungannya. Dikatakan tidak menggurui karena dalam bahtsul masa'il guru hanya berperan sebagai moderator/fasilitator.

Pada pelaksanaan bahtsul masa'il, siswa dihadapkan dengan beberapa masalah faktual yang harus dipecahkan dalam proses pembelajaran. Menurut teori belajar konstruktivistik, pengetahuan akan lebih bermakna apabila dibangun berdasarkan realita lapangan. Semakin banyak siswa berinteraksi dengan obyek dan lingkungannya, pengetahuan dan pemahamannya akan obyek dan lingkungan tersebut akan meningkat dan lebih rinci (Budiningsih, 2005). Keterampilan berpikir kritis yang diamati oleh peneliti dalam pembelajaran Fikih mengggunakan metode bahtsul masa'il ini, di antaranya adalah sikap respek terhadap data dan pendapat, menafsirkan sebuah fenomena dari berbagai sudut pandang, senang bertanya, tanggap terhadap informasi, mampu menghasilkan gagasan, mampu memecahkan masalah secara terorganisir dan sikap kehati-hatian intelektual. Temuan penelitian ini sejalan dengan hasil penelitian Hidayatulloh (2018) yang menyatakan bahwa kegiatan bahtsul masa'il merupakan salah satu metode pembelajaran yang terdapat di lingkungan pesantren yang memungkinkan santri berlatih berpikir kritis, solutif dan kontekstual. Melalui kegiatan bahtsul masa'il tersebut santri dalam berbagai tingkatan dilatih menganalisis dan memberikan jawaban atas persoalan hukum yang terjadi di masyarakat sekitar. Hasil penelitian ini juga memperkuat hasil penelitian yang dilakukan oleh Sarwenda (2014), yang menemukan bahwa metode bahtsul masa'il merupakan salah satu metode pembelajaran di Pesantren Pertanian Darul Fallah Bogor yang terbukti dapat melatih kemampuan berpikir kritis santri. Melalui metode tersebut santri dilatih berpikir kritis lewat kajian kitab-kitab klasik. Mereka berusaha membahas dan mendiskusikan pandangan para ulama terdahulu berkaitan dengan berbagai persoalan dan yang lebih unik lagi di pesantren tersebut memberikan kebebasan kepada siswanya untuk berani memberikan kritik kepada para pendidiknya. Dengan cara seperti itu maka kemampuan berpikir kritis santri bisa terlatih dengan baik

Proses pembelajaran menggunakan metode bahtsul masa'il adalah sejalan dengan tahapan pembelajaran menggunakan model pembelajaran berbasis masalah (problem based learning/PBL). Salah satu keunggulan model pembelajaran ini adalah dapat melatih kemampuan berpikir kritis siswa. Hal ini sejalan dengan hasil penelitian Kek and Huijser (2011), Kong et al., (2014), Nafiah and Suyanto (2014), Markawira, Syah and M, 2014), penelitian Qomariyah (2016), (Iskandar, 2015), dan (Rahmayanti, 2017). Penelitian-penelitian ini dilakukan dalam bidang yang berbeda dan pada jenjang yang beragam dan semua hasil penelitian tersebut menemukan kesimpulan yang sama yakni penggunakan model pembelajaran berbasi masalah (problem based learning) efektif meningkatkan kemampuan berpikir kritis siswa.

Selain itu, bahtsul masa'il menjadi sarana bagi siswa untuk berpartisipasi secara fisik maupun mental dalam membangun struktur pengetahuannya sendiri dengan cara mengkritisi sebuah masalah yang disajikan oleh guru. Sesuai dengan teori yang dikemukakan oleh Gleser, berpikir kritis merupakan suatu sikap mau berpikir secara mendalam tentang masalah-masalah dan hal-hal yang berada dalam jangkauan pengalaman seseorang melalui metode-metode pemeriksaan dan penalaran yang logis disertai keterampilan untuk menerapkan metode-metode tersebut 
(Fisher, 2008). Bentuk partisipasi siswa dalam pelaksanaan metode bahtsul masa'il yang diamati peneliti adalah keaktifan siswa di dalam kelas, kepatuhan terhadap norma belajar, tanggung jawab dalam pembelajaran dan menanggapi serta memecahkan masalah. Pada setiap tahapan bahtsul masa'il, siswa memiliki peran dan tanggung jawabnya masing-masing dalam proses pemecahan masalah. Hal tersebut menuntut siswa untuk berpartisipasi secara total (partisipasi fisik, akal dan mental). Sesuai dengan apa yang dikemukakan oleh Moelyarto Tjokrowinoto dalam Suryobroto (2009), bahwa partisipasi adalah penyertaan fisik, mental, dan emosi seseorang di dalam situasi kelompok yang mendorong mereka untuk mengembangkan daya pikir, perasaan, dan tanggung jawab bersama bagi tercapainya tujuan yang diharapkan. Temuan penelitian ini memperkuat hasil penelitian Muhammad (2017), yang menemukan bahwa kegiatan bahtsul masa' $i l$ adalah aktualisasi nyata prinsipprinsip demokrasi yang mendorong dan memberikan kesempatan bagi setiap peserta berpartisasi dan berperan secara aktif memberikan pendapat-pendapatnya dalam membahas masalah-masalah yang ada..

Meskipun metode bahtsul masa'il telah terbukti efektif dalam meningkatkan daya kritis dan partisipasi siswa, namun dalam penerapannya sebagai metode pembelajaran Fikih di MA, masih ada yang perlu diperhatikan, yaitu peran guru sebagai fasilitator dan sebagai ketua sidang bahtsul masa'il. Masih ada langkah pembelajaran yang belum terlaksana dalam penerapan metode bahtsul masa'il di MA YPI Cikoneng, yaitu evaluasai pemecahan masalah oleh guru. Guru perlu memaksimalkan perannya sebagai ketua sidang bahtsul masa'il yang bertugas untuk memberikan pencerahan dan tabayyun tentang apa yang telah banyak didiskusikan oleh siswa, sehingga siswa dapat menerima kesimpulan berupa pengesahan jawaban atau hukum terkait masalah yang dibahas dalam bahtsul masa'il tersebut.

\section{PENUTUP}

Metode bahtsul masa'il dapat dijadikan sebagai salah alternatif metode pembelajaran Fikih di Madrasah Aliyah. Penerapan metode bahtsul masa'il dalam pembelajaran Fikih di
MA dilaksanakan sejalan dengan model pembelajaran Problem Based Learning (PBL) yang meliputi lima langkah pembelajaran, yaitu orientasi siswa pada masalah, mengorganisasi kegiatan belajar siswa, proses penyelidikan/ pencarian informasi, presentasi hasil pemecahan masalah, dan evaluasi hasil pemecahan masalah. Bahtsul masa'il menjadi sarana bagi siswa untuk berpartisipasi secara fisik maupun mental dalam membangun struktur pengetahuannya sendiri dengan cara mengkritisi sebuah masalah yang disajikan oleh guru sehingga siswa memiliki peran dan tanggung jawab masing-masing dalam bahtsul masa'il yang menuntut mereka untuk berpartisipasi secara total.

Berdasarkan hasil analisis uji beda dua rata-rata nilai daya kritis dan partisipasi antara siswa kelas eksperimen dengan kelas kontrol dalam pembelajaran Fikih di MA YPI Cikoneng Bandung diperoleh nilai signifikansi sebesar 0,000. Hasil tersebut menunjukan bahwa $p<0,05$ yang berarti terdapat perbedaan yang signifikan antara daya kritis dan partisipasi siswa kelas eksperimen yang menggunakan metode bahtsul masa'il dengan siswa kelas kontrol yang tidak menggunakan metode bahtsul masa'il. Berdasarkan hasil analisis $N$ gain juga terdapat perbedaan peningkatan baik untuk aspek daya kritis maupun partisipasi siswa antara kelas eksperimen dengan kelas kontrol. Peningkatan daya kritis dan partisipasi siswa kelas eksperimen lebih tinggi dari pada kelas kontrol. Dengan demikian dapat disimpulkan bahwa penerapan metode bahtsul masa'il cukup efektif dalam meningkatkan daya kritis dan partisipasi siswa pada pembelajaran Fikih di MA YPI Cikoneng Bandung.

Berangkat dari temuan hasil penelitian di atas, dikemukakan saran-saran sebagai berikut: Pertama, bagi guru mata pelajaran Fikih, disarankan dapat terus mempelajari dan menerapkan metode bahtsul masa'il dalam pembelajaran Fikih, karena berdasarkan hasil penelitian ini metode bahtsul masa'il terbukti efektif dalam mengembangkan kemampuan berpikir kritis dan tingkat partisipasi siswa dalam proses pembelajaran. Dengan cara itu diharapkan pembelajaran Fikih di Madrasah Aliyah akan lebih bermakna bagi siswa. Kedua, bagi pengelola Madrasah Aliyah disarankan 
untuk mendukung guru dalam mengimplementasikan metode bahtsul masa'il dengan cara melengkapi sumber belajar secara memadai khususnya buku-buku referensi. Karena untuk keberhasilan pelaksanaan pembalajaran dengan metode bahtsul masa'il ini sangat dibutuhkan kelengkapan buku-buku referensi tersebut. Ketiga, bagi para peneliti, penelitian ini hanya dibatasi pada variabel penerapan metode bahtsul masa'il dalam hubungannya dengan peningkatan daya kritis dan partisipasi siswa dalam pembelajaran Fikih di Madrasah Aliyah YPI Cikoneng Bandung. Oleh karena itu sangat dimungkinkan peneliti lain melakukan kajian yang sama di wilayah yang lebih luas, atau meneliti tentang metode bahtsul masa'il dikaitkan dengan variabelvariabel lainnya seperti pengembangan sikap keberagaamaan yang moderat, nilai tanggung jawab, sikap toleransi, dan sebagainya.

\section{UCAPAN TERIMAKASIH}

Penulis pada kesempatan ini menyampaikan ucapan terima kasih dan penghargaan yang setinggi-tingginya kepada semua pihak yang telah memberikan bantuan dan fasilitas baik langsung maupun tidak langsung dalam proses penelitian dan penulisan laporan hasil penelitian dalam bentuk artikel ini. Secara khusus ucapan terima kasih disampaikan kepada pimpinan Fakultas Ilmu Tarbiyah dan Keguruan UIN Sunan Kalijaga Yogyakarta yang telah memberikan kesempatan kepada penulis untuk melaksanakan kegiatan penelitian. Ucapan terima kasih berikutnya disampikan kepada Kepala Madrasah Aliyah Cikoneng Bandung dan para guru serta siswa yang telah memberi ijin, kesempatan, bantuan kepada penulis untuk melaksanakan kegiatan penelitian ini. Penulis berharap mudahmudahan penelitian ini memberikan manfaat bagi pengembangan ilmu pendidikan Islam terutama terkait dengan pengembangan metode pembelajaran Fikih dan juga bermanfaat bagi Madrasah Aliyah tempat dilaksanakan penelitian ini dalam rangka untuk menyempurnakan metode pembelajaran Fikih, sehingga pembelajaran Fiqih di MA lebih bermakna bagi siswa.

\section{DAFTAR PUSTAKA}

Arifi, A. (2010) Pergulatan Pemikiran Fiqih
'Tradisi' Pola Madzhab. Yogyakarta: eLSAQ Press.

Bono, E. De (2007) Revolusi Berpikir, Mengajari Anak Anda Berpikir Canggih dan Kreatif dalam Memecahkan Masalah dan Memantik Ide-ide Baru. Bandung: Mizan Pustaka.

Budiningsih, C. A. (2005) Belajar dan Pembelajaran. Jakarta: Rineka Cipta.

Emzir (2013) Metodologi Penelitian Pendidikan Kuantitatif dan Kualitatif. Jakarta: RajaGrafindo Persada.

Fisher, A. (2008) Sebuah Pengantar. Jakarta: Erlangga.

Ghozali, I. (2008) Desain Penelitian Eksperimental: Teori, Konsep dan Analisis Data dengan SPSS 16.0. Semarang: Badan Penerbit Universitas Diponegoro.

Hake, R. R. (1999) Analyzing Chane/Gain Score, Dept. of Physics, Indiana University. Available at: www.physics.indiana.edu, $\sim$ sdi , AnalyzingChange-Gain\%0A (Accessed: 27 March 2020).

Hidayatulloh, M. S. (2018) 'Pembelajaran Kontekstual Dalam Kegiatan Bahtsul Masail Santri Di Pondok Pesantren AlMuhibbin Bahrul Ulum Tambakberas Jombang', Nazhruna: Jurnal Pendidikan Islam. doi: 10.31538/nzh.v1i2.50.

Iskandar, S. (2015) 'The Development of Problem-Based Learning Model in Troubleshooting to Enhance Students' Critical Thinking Skills at Automotive Program of Senior Vocational School', EDUTECH. doi: 10.17509/edutech.v14i2.1378.

Janawi (2013) Metodologi dan Pendekatan Pembelajaran. Yogyakarta: Ombak.

Kek, M. Y. C. A. and Huijser, H. (2011) 'The power of problem-based learning in developing critical thinking skills: Preparing students for tomorrow's digital futures in today's classrooms', Higher Education Research and Development. doi: 10.1080/07294360.2010.501074. 
Komalasari, K. (2013) Pembelajaran Kontekstual, Konsep dan Aplikasi. Ke-3. Bandung: Refika Aditama.

Kong, L. N. et al. (2014) 'The effectiveness of problem-based learning on development of nursing students' critical thinking: A systematic review and meta-analysis', International Journal of Nursing Studies. doi: 10.1016/j.ijnurstu.2013.06.009.

Kuswana, W. S. (2013) Taksonomi Berpikir. Kedua. Bandung: Remaja Rosdakarya.

Kuswana, W. S. (2014) Taksonomi Kognitif, Perkembangan Ragam Berpikir. Kedua. Bandung: Remaja Rosdakarya.

Markawira, S., Syah, I. and M, S. (2014) 'Penerapan Model Problem Based Learning (PBL) dalam Meningkatkan Kemampuan Berpikir Kritis', Jurnal Pendidikan dan Penelitian Sejarah.

Menteri Agama (2019) 'Keputusan Menteri Agama Nomor 183 Tahun 2019 tentang Kurikulum PAI dan Bahasa Arab pada Madrasah'. Jakarta: Direktorat KSKK Madrasah, Dirjen Pendis, Kemeneterian Agama RI.

Miri, D. (2005) Solusi Problematika Aktual Hukum Islam. Surabaya: Lajnah Ta'lif wan Nasyar.

Moeliono, A. M. (1990) Kamus Besar Bahasa Indonesia. Ke-3. Jakarta: Balai Pustaka.

Moleong, L. J. (2005) Metodologi Penelitian Kualitatiif. Bandung: Rosdakarya.

Muhammad, H. (2017) 'Bahtsul Masail NU Dan Implementasi Demokrasi', EDUKASI: Jurnal Penelitian Pendidikan Agama dan Keagamaan. doi: 10.32729/edukasi.v3i2.209.

Mukhsin (2012) Model Pembelajaran untuk Meningkatkan Kemampuan Berpikir Kritis Siswa. Bandung: Universitas Pendidikan Indonesia.

Mulyasa, E. (2005) Implementasi Kurikulum2004, Panduan Belajar KBK. Bandung: Rosdakarya.

Mulyasa, E. (2014) Kurikulum Tingkat Satuan Pendidikan. Bandung: Remaja Rosdakarya.
Nafiah, Y. N. and Suyanto, W. (2014) 'Penerapan model problem-based learning untuk meningkatkan keterampilan berpikir kritis dan hasil belajar siswa', Jurnal Pendidikan Vokasi. doi: 10.21831/jpv.v4i1.2540.

Qomariyah, E. N. (2016) 'Pengaruh Problem Based Learning terhadap Kemampuan Berpikir Kritis IPS', Jurnal Pendidikan Dan Pembelajaran.

Rahmayanti, E. (2017) 'Penerapan Problem Based Learning dalam Meningkatkan Kemampuan Berpikir Kritis Peserta Didik pada Pembelajaran Pendidikan Pancasila dan Kewarganegaraan Kelas XI SMA', Prosiding Konferensi Nasional Kewarganegaraan III p-ISSN 2598-5973.

Rajafi, A. (2015) Nalar Fiqih Muhammad Quraish Shihab. Yogyakarta: Istana Publishing.

Rusman (2016) Model-Model Pembelajaran, Mengembangkan Profesionalisme Guru. Jakarta: RajaGrafindo Persada.

Sanjaya, W. (2012) Strategi Pembelajaran Berorientasi Standar Proses Pendidikan. Ke-12. Jakarta: Kencana Prenada Media Group.

Santrock, J. W. (2007) Psikologi Pendidikan. Jakarta: Prenada Media.

Sarasati, A., Harlanu, M. and Sutarno (2016) 'Implementasi Model Student Facilitator And Explaining Materi Microsoft Excel untuk Meningkatkan Motivasi, Sikap dan Hasil Belajar Siswa di SMP Negeri 2 Patebon', Edu Komputika Journal, 3(2), pp. 37-44.

Sardiman (2011) Interaksi dan Motivasi Belajar Mengajar. Jakarta: PT. Raja Grafindo Persada.

Sarwenda, S. (2014) 'Pembelajaran Kritis di Pesantren: Studi Kasus di Pesantren Pertanian Darul Fallah Bogor', TARBIYA: Journal of Education in Muslim Society. doi: 10.15408/tjems.v1i2.1265.

Schunk, D. H. (2012) Learning Theories an Educational Perspective: Teori-Teori Pembelajaran Perspektif Pendidikan. Yogyakarta: Pustaka Pelajar. 
Situmorang, R. M., Muhibbuddin and Khairil (2015) 'Penerapan Model Pembelajaran Problem Based Learning untuk Meningkatkan Hasil Belajar Siswa pada Materi Sistem Ekskresi Manusia', Jurnal EduBio Tropika, 3(2), pp. 87-90.

Soewarno, T. B., Alfan, A. and Wahyudi, A. T. (2015) Buku Guru Fikih Pendekatan Saintifik Kurikulum 2013. Jakarta: Kementerian Agama.

Sopiatin, P. and Sahrani, S. (2011) Psikologi Belajar dalam Perspektif Islam. Bogor: Ghalia Indonesia.

Sugiyono (2014) Metode Penelitian Pendidikan Pendekatan Kuantitatif, Kualitatif, dan $R \& D$. Bandung: Alfabeta.

Suhardin, S. (2018) 'Pengaruh Strategi Pembelajaran Contextual Teaching Learning Dan Integreted Instructional Terhadap Kemampuan Berpikir Kritis Siswa Tentang Zakat', EDUKASI: Jurnal Penelitian Pendidikan Agama dan Keagamaan, 16(2), pp. 124-137. doi: 10.32729/edukasi.v16i2.463.

Sukiman (2017) Sistem Penilaian Pembelajaran. Yogyakarta: Media Akademi.

Sukmadinata, N. S. (2010) Metode Penelitian Pendidikan. Keenam. Bandung: Remaja Rosdakarya.

Suparno, P. (2001) Filsafat Konstruktivisme dalam Pendidikan. Yogyakarta: Kanisius.

Suprihatiningrum, J. (2013) Strategi Pembelajaran, Teori dan Aplikasi. Yogyakarta: Ar-RUZZ Media.
Suryobroto (2009) Proses Belajar Mengajar di Sekolah, Wawasan Baru Beberapa Metode Pendukung dan Beberapa Komponen Layanan Khusus. Jakarta: Rineka Cipta.

Susanto, A. (2015) Teori Belajar dan Pembelajaran di Sekolah Dasar. Ke-3. Jakarta: Prenadamedia Group.

Taufiq, U. (2019) Hasil wawancara. Bandung.

W.Airasian, P. et al. (2010) Kerangka Landasan untuk Pembelajaran, Pengajaran, dan Asesmen: Revisi Taksonomi Bloom. I. Edited by L. W. Anderson and D. R. Krathwohl. Yogyakarta: Pustaka Pelajar.

Widana, I. W. (2017) Modul Penyusunan Soal Higher Order Thinking Skills (HOTS). Jakarta: Direktorat Pembinaan SMA Ditjen Pendidikan Dasar dan Menengah.

Winarti, C., Sunarmo, W. and Istiyono, E. (2015) 'Pengembangan Model dan Perangkat Pembelajaran untuk Meningkatkan Kemampuan Berpikir Tingkat Tinggi', in Makalah Seminar Nasional Pendidikan Sains. Surakarta: FIKP UNS, Magister Pendidikan Sains dan Doktor Pendidikan IPA.

Wiyani, I. M. N. A. (2013) Psikologi Pendidikan, Teori dan Aplikasi dalam Proses Pembelajaran. Yogyakarta: ArRUZZ Media.

Zahro, A. (2004) Lajnah Bahtsul Masa'il 19261999 Tradisi Intelektual NU. Yogyakarta: LkiS. 